\title{
Effect of pulsed electromagnetic therapy on bone mineral density of female athletes
}

\author{
Asmaa M. El-Bandrawy ${ }^{1 *}$, Azza Barmoud Nashed ${ }^{1}$ and Hassan O. Ghareeb ${ }^{2}$
}

*Correspondence: asma_elbandrawy@yahoo.com

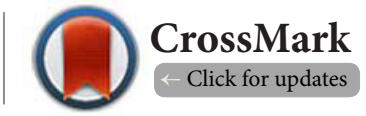

'Department of Physical Therapy for Woman's Health, Cairo University, Giza, Egypt.

${ }^{2}$ Faculty of Medicine, Department of Obstetrics and Gynecology, Cairo University, Giza, Egypt.

\begin{abstract}
Background: The prevalence of menstrual irregularities and low bone mineral density (BMD) varies widely in the general population and in the athletic community. Pulsed electromagnetic therapy(PEMT) may stimulate bone formation and prevent bone loss.

Objective: The aim of the present study was to evaluate the effect of low-frequency pulsed electromagnetic field therapy (PEMFT) on bone mineral density (BMD) in female athletes.

Subjects and methods: A total of 40 female athletes selected from the outpatient clinic of faculty of Physical Therapy, Cairo University, Cairo. Their age was ranged between 15-25 years, BMI: 20-24.9 kg/ $\mathrm{m}^{2}$. They were randomly allocated into two groups: studygroup (A), and the control group (B). The pulsed electromagnetic field therapy (PEMFT) at low frequency $33 \mathrm{~Hz}$ and intensity of 50 gauss which equal $60 \%$ of the maximum intensity was applied for $30 \mathrm{~min}$, three times weekly for 4 months on the lumbar and hip region for the study group (A). All participants adhered to the calcium and vitamin D medications prescribed by their physicians. BMD was evaluated using dual-energy X-ray absorptiometry for both groups $(\mathrm{A} \& \mathrm{~B})$ before and after treatment.

Results: The results revealed a significant increase in BMD of right neck femur and lumber spine (L1-4) in both groups after the treatment program (study group, $\mathrm{P}<0.001 \& 0.002$ and control group, $\mathrm{P}<0.001 \& 0.001$ respectively). Between groups, there were significant differences in BMD of right neck femurand lumber spine (L1-4) but in favor of group A $(\mathrm{P}<0.001 \& 0.009)$. The mean values in BMD of Rt neck femur after treatment were $1.021 \pm 0.067,0.959 \pm 0.053$ in both groups $\mathrm{A}$ and $\mathrm{B}$, respectively. The mean values in $\mathrm{BMD}$ of lumber spine (L1-4) were 1.044 $\pm 0.116,0.970 \pm 0.019$ in both groups A and B, respectively.
\end{abstract}

Conclusion: PEMFT is a useful therapeutic procedure to increase BMD in female athletes Keywords: BMD, Female, Athelete, PEMF, Vitamin D

\section{Introduction}

The prevalence of menstrual irregularities, eating disorder, and low BMD varies widely in the overall public and in the athletic community [1]. The female athlete triad is a syndrome that has been reported in female athletes with three interrelated components: eating disorder, decreased frequency of menstrual cycle, and osteoporosis $[2,3]$.

Endurance athletes have diminished levels of sex hormones, which may cause physiologic changes that enhance bone loss. This may cause relative osteoporosis despite the loading of the bone during exercise, which would regularly increase bone mineral density. Untimely osteoporosis might be irreversible, making athletesprogress toward osteoporosis at a prior age and have a potential risk of fracture later in life [4].

The spectrum of menstrual function ranges from eumenorrhea to amenorrhea. Eumenorrhea is characterized by monthly cycle every 28 days. Amenorrhea classified into primary and secondary subsets; primary amenorrhea is the disappearance of menarche after age 15, and secondary amenorrhea is the stoppage of menses for three consecutive cycles after 
menarche. In the female athlete, menstrual function should be assessed and corrected if it is abnormal because estrogen has an important role in bone wellbeing and remodeling [5].

The diminished rate of bone building in adolescent athletes is especially concerning, since bone mass gains during childhood and adolescence are critical for the attainment of maximal peak bone mass and prevention of osteoporosis in adulthood $[6,7]$.

The established interventions for osteoporosis are pharmacological, which fall in two categories, i.e., enhancing bone formation and inhibition of bone resorption, but each have their own adverse effects $[8,9]$. Because of these undesired consequences of drug applications, alternative methods have been investigated for a long period of time. One of the therapeutic physiotherapy modality proposed to be a safe and effective is pulsed electromagnetic field [10].

Pulsed electromagnetic field (PEMF) has been proved to improve bone biomechanical properties, prevent bone mass loss, and prevent bone microarchitecture decay [11]. PEMFs may stimulate bone formation, possibly by enhancing osteoplastic activity, in postmenopausal women with osteoporosis [12].

It is generally accepted that optimizing vitamin $D$ and calcium intake in young women is necessary for bone health; particularly vitamin $D$ levels are frequently observed to be low in this age group [13].

Calcium and vitamin D are inexpensive therapies which enhance bone health. Calcium is essential for bone formation and is lost from the body through urine and the renal system every day, and needs to be replaced. Low serum calcium leads to increased parathyroid hormone and increased bone loss. Therefore, maintaining adequate calcium intake is important. Vitamin $D$ is essential for bone health. It is integral to calcium homeostasis and increases intestinal absorption of calcium [14].

\section{Subjects and methods}

This study is a prospective, randomized controlled study. Sixty female athletes who had a previous history of participation in Organization and athletic events for at least 3 years (age:1525 years, BMl :20-24.9 $\mathrm{kg} / \mathrm{m}^{2}$ ) were contacted for this study. Eight of them didn't wish to participate in the study and nine were not fulfilling inclusion criteria and therefore couldn't be included in the study. 43 women gave their informed consent to participate in the study. The forty three remaining women were randomly allocated into two groups: study group (group $A ; n=22$ ), and the control group (group $B ; n=21$ ). Three had moved away long distance and were unable to attend for bone mineral density (BMD) measurement, so only forty patients were available for post treatment assessment Figure 1.

All of the participants were oligomenorrheic, who had 4-9 menstrual cycles in the last year. They were selected fromout patient clinic of faculty of Physical Therapy, Cairo University to participate in this study. Exclusion criteria were smoking, any pelvic pathology, respiratory diseases like asthma (chronic use of steroids), diabetes, thyroid diseases, cardiac pacemakers,

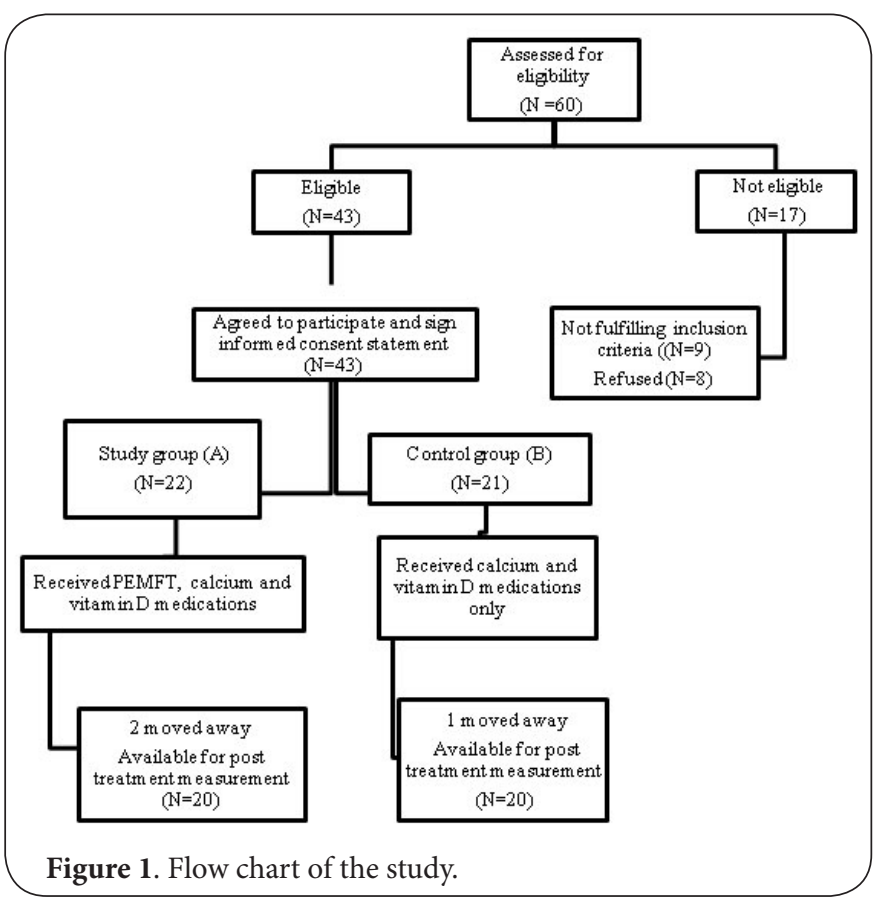

pregnancy, metal implants with ferrous (iron) component, oral contraceptives or any hormonal treatment in the previous six months.

Sample size was calculated on the basis of an estimated large Cohen effect size ( $F=0.53)$ using $95 \%$ power and $5 \%$ significance level that determined a realistic sample size of 40 participants for this study [15].

Patient randomization was reported by physical therapist who did not belong to the study. Reported patients were randomly assigned into either PEMFT group (study group A) or the control group (B) by using the computer generated random numbers. Allocation was concealed in sequentially numbered opaque envelopes. An independent person who was blinded to the research protocol involved in the trial operated the random assignment. All participants adhered to the calcium and vitamin $\mathrm{D}$ medications prescribed by their physicians. All females were havinga balanced nutritional diet(adequate protein, carbohydrate and fat intake). All patients were given full explanation of the treatment protocol, and signed informed consents were obtained before participation. This study was approved by the Ethics Committee for Scientific Research of the Faculty of Physical Therapy, Cairo University.

\section{Evaluation}

All participant females underwent the same evaluation procedure. The main evaluated parameters were BMD of the lumbar spine (L1-L4) and right femur in $\mathrm{mg} / \mathrm{cm}^{2}$ evaluated using (DXA, Lunar DPX -IQ software version 4.7, Lunar CO,Wi USA). Evaluations of BMD using DXA were performed before and after completion of the treatment program by a specialized physician who was blinded to the study. Demographic 
data including age(Years) and BMI (weight $\mathrm{kg} / \mathrm{m}^{2}$ ) were all recorded before treatment.

\section{Pulsed electromagnetic field therapy(PEFT) for study group(A)}

Automatic PMT Quattro PRO PEMF device was applied at low frequency $33 \mathrm{~Hz}$ and intensity of 50 gauss which equal $60 \%$ of the maximum intensity with the rectangular waveform supplied by the applicators. The participant was positioned in a comfortable supine position while wearing light cotton clothes. After properly cleaning the skin with alcohol, the solenoids were adjusted and positioned under the lumber-hip region $30 \mathrm{~min} / \mathrm{session}, 3$ sessions/week for 16 weeks.

\section{Supplementation of vitamin D and Calcium for both groups}

Both groups received $1200 \mathrm{mg}$ of calcium and $1000 \mathrm{IU}$ of vitamin D dailyfor 16 weeks as prescribed by their physician [16].

Statistical analysis was conducted using SPSS for windows, version 19 (SPSS, Inc., Chicago, IL). Normality test of data using Shapiro-Wilk test was used, that reflect the data was normally distributed for all dependent variables, so parametric analysis was used. Results are expressed as mean \pm standard deviation. Comparison between variables measured pre- and posttreatment in the same group was performed using paired $t$ test. $P$ value $\leq 0.05$ was considered significant.

\section{Results}

Physical characteristics for both groups (A\&B)

The demographic characteristics of both groups (A\&B) at baseline (age and $\mathrm{BMI}$ ) revealed no significant differences between the two groups before treatment Table 1.

BMD of right neck femurpre- and post-treatment for both groups $(A, B)$

$\mathrm{BMD}\left(\mathrm{mg} / \mathrm{cm}^{2}\right)$ of Rt neck femur before and after treatment for both groups ( $A$ and $B$ ) revealed statistically significant increases in BMD for both groups (A\&B) after treatment $(1.021 \pm 0.067$, $0.959 \pm 0.053 \mathrm{mg} / \mathrm{cm}^{2}$ ) compared to its corresponding value before treatment $\left(0.943 \pm 0.073,0.935 \pm 0.064 \mathrm{mg} / \mathrm{cm}^{2}\right)$. Comparison between both groups $(A)$ and $(B)$, revealed a statistically non-significant difference in BMD of Rtneck femur before the treatment $(F=0.155 \& P=0.696)$ and a statistically significant

Table 1. Physical characteristics for both groups (A\&B).

\begin{tabular}{|c|c|c|c|c|c|}
\hline \multirow[t]{2}{*}{ Variables } & \multirow[t]{2}{*}{ Groups } & \multirow[t]{2}{*}{ Mean } & \multicolumn{2}{|c|}{ Comparison } & \multirow[t]{2}{*}{$\mathrm{S}$} \\
\hline & & & t-value & P-value & \\
\hline \multirow[t]{2}{*}{ Age (yrs) } & Group (A) & $19.35 \pm 2.796$ & 0.210 & 0.835 & NS \\
\hline & Group (B) & $19.55 \pm 3.203$ & & & \\
\hline \multirow{2}{*}{$\begin{array}{l}\mathrm{BMI} \\
\mathrm{kg} / \mathrm{m}^{2}\end{array}$} & Group (A) & $22.04 \pm 1.390$ & 0.056 & 0.955 & NS \\
\hline & Group (B) & $22.02 \pm 1.422$ & & & \\
\hline
\end{tabular}

Data are expressed as mean \pm SD. $\mathrm{P}<0.05=$ significant. S: significant, NS: not significant difference after the treatment in favor of group $(A)(F=25.250$ $\& \mathrm{P}=0.001$ ) Table 2.

BMD ( $\left.\mathrm{mg} / \mathrm{cm}^{2}\right)$ of lumber spine (L1-4)pre- and posttreatment for both groups $(\mathrm{A} \& \mathrm{~B})$

BMD of lumber spine before and after treatment for both groups ( $A$ and $B$ ) showed statistically significant increases in BMD for both groups (A\&B) after treatment $(1.044 \pm 0.116$, $0.970 \pm 0.019 \mathrm{mg} / \mathrm{cm}^{2}$ ) respectively compared to its corresponding value before treatment $\left(0.951 \pm 0.068,0.943 \pm 0.019 \mathrm{mg} / \mathrm{cm}^{2}\right)$ respectively. Comparison between both groups (A) and (B), revealed a statistically non-significant difference in $B M D$ of lumber spine before the treatment $(F=0.223 \& \mathrm{P}=0.640)$ and a statistically significant difference after the treatment in favor of group (A) $(F=7.608 \& P=0.009)$ Table 3.

\section{Discussion}

Amenorrhea is common infemale athletes, especially those participating in sports, others experience it because of chronically deficient caloric intake that does not compensate for energy expenditure. Complications associated with amenorrhea include decreased peak bone mass in adolescence, and increased therisk of stress fractures [17].

A study by Drinkwater et al. [18] compared lumbar spine bone mineral density (BMD) between eumenorrheic athletes and amenorrheic athletes. Vertebral mineral density was significantly lower in the amenorrheic group than in the eumenorrheic group. So, this study was carried out to determine the Effect of PEMFT on bone mineral densityin female athlete.

This study revealed significant increase in BMD in the study group,this was supported by He et al., [19] who proved that, PEMF may be very effective for bone mass maintenance in subjects with osteoporosis via inhibition of osteoclast formation and activation of osteoblasts.

Increased in BMD caused by PEMF may be caused by the actuation of extracellular signal-regulated kinase (ERK), mitogen-activated protein kinase (MAPK) and prostagland in synthesis, which may havea stimulatory impacts on bone [20-22]. In vitro studies proved that a variety of growth factors that are necessary for bone metabolism are affected, including bone morphogenetic protein 2 (BMP-2), transforming growth factor beta (TGF- $\beta$ ) and insulin-like growth factor II (IGF-II) [23-25].

Pulsed electromagnetic field (PEMF) increases BMD inosteoporotic (OP) patients. Several previous studies used PEMF to prevent steroid-associated bone lossand proved that PEMF improved serum lipid levels $[26,27]$. Furthermore, PEMF affects calcium ion channels in cell membranes [28] and enhances brain-derived neurotrophic factor (BDNF) expression through an L-type voltage-gated calcium channel [29].

In contrast,Van der Jagt et al., [30] used in vivo micro CT scanning and could recognize little bone changes in time. Subtle contrasts in the experimental set-up might clarify the differences in study outcomes in the literature. Since PEMF treatment is safe, further experimental studies on the effect 
Table 2. Mean values of BMD for right neck femur measured pre- and post-treatment for both groups (A, B).

\begin{tabular}{|c|c|c|c|c|c|}
\hline & $\begin{array}{l}\text { Study group (A) } \\
(n=20)\end{array}$ & $\begin{array}{l}\text { Control group } \\
(\mathrm{B})(\mathrm{n}=20)\end{array}$ & F value & P value & $\begin{array}{l}\text { Partial Eta } \\
\text { Squared }\end{array}$ \\
\hline Pre-treatment & $0.943 \pm 0.073$ & $0.935 \pm 0.064$ & 0.155 & 0.696 & 0.004 \\
\hline Post-treatment & $1.021 \pm 0.067$ & $0.959 \pm 0.053$ & 25.250 & $0.001^{\star}$ & 0.406 \\
\hline$\%$ change & $8.27 \% \uparrow \uparrow$ & $2.57 \% \uparrow \uparrow$ & & & \\
\hline$t$ and $p$ values & $-6.691 \& 0.001^{*}$ & $-6.449 \& 0.001^{\star}$ & & & \\
\hline
\end{tabular}

Data are expressed as mean \pm SD. $\mathrm{p}>0.05=$ not significant. ${ }^{\star} \mathrm{p}<0.05=$ significant.

Table 3. Mean values of BMD for lumber spine measured pre- and post-treatment for both groups (A, B).

\begin{tabular}{llllll}
\hline & $\begin{array}{l}\text { Study group (A) } \\
(\mathbf{n = 2 0})\end{array}$ & $\begin{array}{l}\text { Control group (B) } \\
(\mathbf{n}=\mathbf{2 0})\end{array}$ & F value & P value & $\begin{array}{l}\text { Partial Eta } \\
\text { Squared }\end{array}$ \\
\hline Pre-treatment & $0.951 \pm 0.068$ & $0.943 \pm 0.019$ & 0.223 & 0.640 & 0.006 \\
Post-treatment & $1.044 \pm 0.116$ & $0.970 \pm 0.019$ & 7.608 & $0.009^{*}$ & 0.171 \\
\% change & $9.78 \% \uparrow \uparrow$ & $2.86 \% \uparrow \uparrow$ & & & \\
$\mathbf{t}$ and p values & $-3.639 \& 0.002^{*}$ & $-6.249 \& 0.001^{*}$ & & & \\
\hline
\end{tabular}

Data are expressed as mean \pm SD.p $>0.05=$ not significant. ${ }^{*} \mathrm{p}<0.05=$ significant.

of PEMF on bonedensity can better be performed directly on humans, disposing of the potential interpretation issues among animals and humans.

This study revealed significant increase in BMD in the control group (B) who adhered to the calcium and vitamin $D$ medications, in addition to the direct effects on bone, vitamin $D$ has been associated with muscle strength. As vitamin $D$ receptors are found in different tissues, including muscle tissue, their activation leads to muscle protein synthesis. In this way, vitamin D supplements may improve muscle strength, and reduce the danger of falls [31].

The mechanism of the impact of calcium and vitamin $D$ is thought to be related todecreasing bone loss [32]. It is additionally possible that the advantageous impacts of vitamin $D$ in people with high calcium intake resulted from particular impacts of $25 \mathrm{OHD}$ on decreasing parathyroid hormone creation [33] or an impact on local formation of calcitriolin bone cells [34].

\section{Conclusion}

PEMFT is a useful therapeutic procedure to increase BMD of female athletes.

\section{Competing interests}

The authors declare that they have no competing interests.

\section{Authors' contributions}

\begin{tabular}{|l|c|c|c|}
\hline Authors' contributions & AME & ABN & HOG \\
\hline Research concept and design & $\checkmark$ & -- & -- \\
\hline Collection and/or assembly of data & $\checkmark$ & $\checkmark$ & $\checkmark$ \\
\hline Data analysis and interpretation & -- & $\checkmark$ & $\checkmark$ \\
\hline Writing the article & $\checkmark$ & -- & -- \\
\hline Critical revision of the article & -- & $\checkmark$ & -- \\
\hline Final approval of article & $\checkmark$ & $\checkmark$ & $\checkmark$ \\
\hline
\end{tabular}

\section{Acknowledgement}

The authors thank all the participants in this study for their cooperation.

Publication history

Editor: Mohammad H. Hadadzadeh, Wheeling Jesuit University, USA. Received: 13-Apr-2018 Final Revised: 06-Jun-2018

Accepted: 11-Jun-2018 Published: 24-Jun-2018

\section{References}

1. Dusek T. Influence of high intensity training on menstrual cycle disorders in athletes. Croat Med J. 2001; 42:79-82. | Pdf | PubMed

2. Thein-Nissenbaum JM and Carr KE. Female athlete triad syndrome in the high school athlete. Phys Ther Sport. 2011; 12:108-16. | Article | PubMed

3. Thein-Nissenbaum JM, Rauh MJ, Carr KE, Loud KJ and McGuine TA. Associations between disordered eating, menstrual dysfunction, and musculoskeletal injury among high school athletes. J Orthop Sports Phys Ther. 2011; 41:60-9. | Article | PubMed

4. Voss LA, Fadale PD and Hulstyn MJ. Exercise-induced loss of bone density in athletes. J Am Acad Orthop Surg. 1998; 6:349-57. | Article | PubMed

5. Taraneh Gharib Nazem BA, Kathryn E and Ackerman MD. Sports Health. The Female Athlete Triad. 2012; 4:302-311.

6. Golden $\mathrm{NH}$ and Abrams SA. Optimizing bone health in children and adolescents. Pediatrics. 2014; 134:e1229-43. | Article | PubMed

7. NIH Consensus Development Panel on Osteoporosis Prevention, Diagnosis, and Therapy, March 7-29, 2000: highlights of the conference. South Med J. 2001; 94:569-73. I PubMed

8. Gallacher SJ and Dixon T. Impact of treatments for postmenopausal osteoporosis (bisphosphonates, parathyroid hormone, strontium ranelate, and denosumab) on bone quality: a systematic review. Calcif Tissue Int. 2010; 87:469-84. | Article | PubMed

9. Rizzoli R, Reginster JY, Boonen S, Breart G, Diez-Perez A, Felsenberg D, Kaufman JM, Kanis JA and Cooper C. Adverse reactions and drug-drug interactions in the management of women with postmenopausal osteoporosis. Calcif Tissue Int. 2011; 89:91-104. | Article | PubMed Abstract | PubMed FullText 
El-Bandrawy et al, Physical Therapy and Rehabilitation 2018, http://www.hoajonline.com/journals/pdf/2055-2386-5-7.pdf

10. Cieślińska-Świder J. Review of orthodontic therapies used in rheumatoid art of inflammation. Rehabil Prakt. 2014; 4:64-69.

11. Garland DE, Adkins RH, Matsuno NN and Stewart CA. The effect of pulsed electromagnetic fields on osteoporosis at the knee in individuals with spinal cord injury. J Spinal Cord Med. 1999; 22:239-45. I PubMed

12. Nicola Giordano, Emilio Battisti, Simone Geraci, Marco Fortunato, Simone Geraci, Luigi Gennari, Clorinda Santacroce, Mario Rigato, Luigi Gennari and Carlo Gennari.Effect of electromagnetic fields on bone mineral density and biochemical markers of bone turnover in osteoporosis: a single-blind, randomized pilot study. 2001; 62:187-193. | Article

13. Constantini NW, Arieli R, Chodick G and Dubnov-Raz G. High prevalence of vitamin D insufficiency in athletes and dancers. Clin J Sport Med. 2010; 20:368-71. | Article | PubMed

14. IOM (Institute of Medicine). Dietary Reference Intakes for Calcium and Vitamin D. Washington (DC): National Academies Press. 2011.

15. Wittes J. Sample size calculations for randomized controlled trials. Epidemiol Rev. 2002; 24:39-53. I PubMed

16. Catharine Ross, JoAnn E. Manson, Steven A. Abrams, John F. Aloia, Patsy M. Brannon, Steven K. Clinton, Ramon A. Durazo-Arvizu, J. Christopher Gallagher, Richard L. Gallo, Glenville Jones, Christopher S. Kovacs, Susan T. Mayne, Clifford J. Rosen and Sue A. Shapses. The 2011 Report on Dietary Reference Intakes for Calcium and Vitamin D from the Institute of Medicine: What Clinicians Need to Know. 2011; 96:53-58.

17. Ihle $R$ and Loucks $A B$. Dose-response relationships between energy availability and bone turnover in young exercising women. $J$ Bone Miner Res. 2004; 19:1231-40. | Article | PubMed

18. Drinkwater BL, Nilson K, Chesnut $\mathrm{CH}, 3$ rd, Bremner WJ, Shainholtz $\mathrm{S}$ and Southworth $\mathrm{MB}$. Bone mineral content of amenorrheic and eumenorrheic athletes. N Engl J Med. 1984; 311:277-81. | Article | PubMed

19. He Z, Selvamurugan N, Warshaw J and Partridge NC. Pulsed electromagnetic fields inhibit human osteoclast formation and gene expression via osteoblasts. Bone. 2018; 106:194-203. | Article | PubMed

20. Chang $\mathrm{K}$ and Chang $\mathrm{WH}$. Pulsed electromagnetic fields prevent osteoporosis in an ovariectomized female rat model: a prostaglandin E2-associated process. Bioelectromagnetics. 2003; 24:189-98. | Article | PubMed

21. Nie $\mathrm{K}$ and Henderson A. MAP kinase activation in cells exposed to a 60 Hz electromagnetic field. J Cell Biochem. 2003; 90:1197-206. | Article | PubMed

22. Schnoke M and Midura RJ. Pulsed electromagnetic fields rapidly modulate intracellular signaling events in osteoblastic cells: comparison to parathyroid hormone and insulin. J Orthop Res. 2007; 25:933-40. | Article I PubMed

23. Aaron RK, Wang S and Ciombor DM. Upregulation of basal TGFbeta1 levels by EMF coincident with chondrogenesis--implications for skeletal repair and tissue engineering. J Orthop Res. 2002; 20:233-40. | Article | PubMed

24. Guerkov HH, Lohmann CH, Liu Y, Dean DD, Simon BJ, Heckman JD, Schwartz Z and Boyan BD. Pulsed electromagnetic fields increase growth factor release by nonunion cells. Clin Orthop Relat Res. 2001; 265-79. | PubMed

25. Jing D, Cai J, Wu Y, Shen G, Li F, Xu Q, Xie K, Tang C, Liu J, Guo W, Wu X, Jiang $M$ and Luo $E$. Pulsed electromagnetic fields partially preserve bone mass, microarchitecture, and strength by promoting bone formation in hindlimb-suspended rats. J Bone Miner Res. 2014; 29:2250-61. | Article I PubMed

26. Li JP, Chen S, Peng H, Zhou JL and Fang HS. Pulsed electromagnetic fields protect the balance between adipogenesis and osteogenesis on steroidinduced osteonecrosis of femoral head at the pre-collapse stage in rats. Bioelectromagnetics. 2014; 35:170-80. | Article | PubMed

27. Ding S, Peng H, Fang HS, Zhou JL and Wang Z. Pulsed electromagnetic fields stimulation prevents steroid-induced osteonecrosis in rats. $B M C$ Musculoskelet Disord. 2011; 12:215. | Article | PubMed Abstract | PubMed FullText

28. Shah JP, Midkiff P, Brandt PC and Sisken BF. Growth and differentiation of PC6 cells: the effects of pulsed electromagnetic fields (PEMF). Bioelectromagnetics. 2001; 22:267-71. | PubMed

29. Li Y, Yan X, Liu J, Li L, Hu X, Sun H and Tian J. Pulsed electromagnetic field enhances brain-derived neurotrophic factor expression through L-type voltage-gated calcium channel- and Erk-dependent signaling pathways in neonatal rat dorsal root ganglion neurons. Neurochem Int. 2014; 75:96-104. | Article | PubMed

30. van der Jagt OP, van der Linden JC, Waarsing JH, Verhaar JA and Weinans $\mathrm{H}$. Systemic treatment with pulsed electromagnetic fields do not affect bone microarchitecture in osteoporotic rats. Int Orthop. 2012; 36:15016. | Article | PubMed Abstract | PubMed FullText

31. Zhu K, Austin N, Devine A, Bruce D and Prince RL. A randomized controlled trial of the effects of vitamin $D$ on muscle strength and mobility in older women with vitamin D insufficiency. J Am Geriatr Soc. 2010; 58:2063-8. | Article | PubMed

32. McKane WR, Khosla S, Risteli J, Robins SP, Muhs JM and Riggs BL. Role of estrogen deficiency in pathogenesis of secondary hyperparathyroidism and increased bone resorption in elderly women. Proc Assoc Am Physicians. 1997; 109:174-80. | PubMed

33. Ritter CS, Armbrecht HJ, Slatopolsky E and Brown AJ. 25-Hydroxyvitamin D(3) suppresses PTH synthesis and secretion by bovine parathyroid cells. Kidney Int. 2006; 70:654-9. | Article | PubMed

34. Atkins GJ, Anderson PH, Findlay DM, Welldon KJ, Vincent C, Zannettino AC, O'Loughlin PD and Morris HA. Metabolism of vitamin D3 in human osteoblasts: evidence for autocrine and paracrine activities of 1 alpha,25-dihydroxyvitamin D3. Bone. 2007; 40:1517-28. | Article | PubMed

\section{Citation:}

El-Bandrawy AM, Nashed AB and Ghareeb HO. Effect of pulsed electromagnetic therapy on bone mineral density of female athletes. Phys Ther Rehabil. 2018; 5:7. http://dx.doi.org/10.7243/2055-2386-5-7 